\title{
COVID-19 КАК НЕГАТИВНЫЙ «СТАРТАП» РАСКОЛА ГЛОБАЛИЗИРУЮЩЕГОСЯ МИРА
}

\author{
Пунченко О. П.
}

\begin{abstract}
В статье исследуется новый подход к становлению глобализации на территории Европьл. Раскрывается «геометрия» мылиления современных западных теоретиков глобализации. Проанализировано «достраивание» содержания конщепта «глобализация», отображающее форму движения мысли глобалистов. COVID-19 раскрылт как глобальный гео-, био-, соичильный «квант», негативно воздействующий на все сферы сочиокультурного бытия человечества. Понятие кванта использовано для объяснения сущности глобальных макрообъектов и мегасдвигов в системе общественного производства. Установлено, что COVID-19 как природный патоген внес в ритм социальной жизни раскол, хаос, который перерос в социальный страх, что резко осложняет проблему самоорганизащии общественного развития.
\end{abstract}

Ключевые слова: глобализаџия, «геометрия» мылиления, «достраивание», пандемия, сочичальный «квант», хаос, сочичальный страх, политика, экономика, финансь.

\section{COVID-19 AS A NEGATIVE STARTUP OF THE SPLIT OF THE GLOBALIZING WORLD}

The article examines a new approach to the establishment of globalization in Europe. The "geometry" of thinking of modern Western theorists of globalization is revealed. The article analyzes the "completion" of the content of the notion "globalization", which reflects the direction of globalist thought. COVID-19 is revealed as a global social "quantum" of negative impact on all spheres of socio-cultural life. The concept of "quantum" is used to explain the essence of global macroobjects and mega-shifts in the system of social production. The author argues that COVID-19 as a natural pathogen has split and chaos into the rhythm of social life which have developed into social fear, which sharply complicates the selforganization of social development.

Keywords: globalization, "geometry of thinking”, “completion”, pandemic, social "quantum”, chaos, social fear, politics, economy, finance.

\section{1. Колесо глобализации XX - начала XXI в.}

В структуре современного научного знания среди множества конструктов, характеризующих различные стороны бытия социума, особое место принадлежит

* Пунченко Олег Петрович - д. ф. н., профессор кафедры стандартизации, оценки соответствия и образовательных измерений Одесской государственной академии технического регулирования и качества. E-mail: olegpetr02.09@gmail.com.

Pounchenko, Oleg P. - Doctor of Philosophy, Professor of the Department of Standardization, Conformity Assessment and Educational Measurements, Odessa State Academy of Technical Regulation and Quality. E-mail: olegpetr02.09@gmail.com. 
исследованию содержания и обоснованию сущности концепта «глобализация». Этот концепт в философской и научной литературе начал широко использоваться лишь во второй половине XX в. и стал фактически одним из стереотипов мышления современности.

Когда концепт «глобализация» был введен в научный оборот, то задача исследователей прежде всего сводилась к поиску и выработке наиболее оптимального определения глобализации, к эксплицитному выражению того, что в содержании этого концепта заложено имплицитно. Ведь глобализация «без конкретизации - это концепт, - отмечает Ф. Фернандес-Арместро, - в существовании которого можно сомневаться» [Фернандес-Арместро 2009: 40], и если до 90-х гг. XX в. содержание этого концепта не было отражено в зарубежных и отечественных словарях и энциклопедиях, то это означает, что данный концепт отсутствовал в научном информационном обороте.

Глобализация как социальная реальность возникла не в стороне от столбовой дороги цивилизационного развития человечества. В конце XX в. она конкретизировала свое новое содержание, но ее истоки необходимо искать в других предыдущих формах, связанных с устремлением развитых стран в борьбе за рынки сбыта, источники сырья, использованием дешевой рабочей силы, что стало важнейшими источниками прибылей монополий сильных стран и привело к становлению колоний. Следующей формой выступил неоколониализм как система неравноправных не только экономических, но и политических отношений, навязываемых сильными государствами слабым, как форма косвенного контроля над ними с использованием политического, экономического (санкций) и военного давления. Эти этапы в истории человечества в современной глобалистике часто обозначают как протоглобализацию, ведя отсчет от завоеваний Колумба. Эта точка отсчета принадлежит Х. Дж. Маккиндеру, который писал еще в 1904 г., что «отныне же в послеколумбовую эпоху нам придется иметь дело с замкнутой системой, и вполне возможно, что будет система глобального масштаба» [Маккиндер 2003]. Фактически это был первый теоретический конструкт будущего глобального мира.

Анализ протоглобализации и глобализационных процессов современности подтверждает мысль А. Н. Чумакова, что глобализация - это «закономерный естественно-исторический процесс становления планетарных структур, связей и отношений в различных сферах общественной жизни» [Чумаков 2020: 6].

Исследователь глобализации Д. Родрик в работе «Парадокс глобализации» [Родрик 2014: 22-23] утверждает, что крах, видимо, протоглобализации, начался еще в 1914 г. и сейчас ожидается новый крах глобализации, связанный с борьбой за рынки сбыта. Если в 1914 г. причиной краха явился сбой экономических связей, то сегодня эта причина не сошла с повестки дня. Но этот год еще и начало Первой мировой войны, где главной причиной была борьба за передел уже поделенного мира, и естественно, за рынки сбыта. Это экономический аспект краха протоглобализации, а военные действия, связанные с политическим аспектом доминированием над Европой, Германия проиграла. К этому же времени начинает развертываться борьба народов против колониализма и неоколониализма, а поскольку, как выше было отмечено, это составляющие протоглобализации, то в 1914 г. 
закладываются основы ее краха. И сводить крах глобализации в 1914 г. к экономическим проблемам - это узко.

Но стрелу направленности глобализации XX в. лучше всего анализировать с работы В. И. Ленина «О лозунге Соединенных Штатов Европы» (1915 г.). Дело в том, что Германия осознала свое военное бессилие стать главной державой Европы. Развертывая военные походы, она часто терпела поражения: Ледовое побоище в России 1242 г.; Грюнвальское поражение 1410 г.; внутренние войны XVIXVII вв. не укрепили единство Германии, а наоборот, усилили децентрализацию страны; что же касается XX в., то он для Германии - особенный. Страна развязала Первую и Вторую мировые войны и обе проиграла.

Но проигрыш во Второй мировой войне оказался для Германии своеобразным подарком от союзников - США, Великобритании и Франции. Дело в том, что в 1946 г. У. Черчилль разделил мир «железным занавесом» на две системы - капитализма и социализма (в этом году исполняется 75 лет его фултонской речи). С декабря 1946 г. в самом центре Европы создается государственное образование Бизония. Это территориальное объединение британской и американской оккупационных зон, которое рассматривалось как форпост на границе с лагерем социализма. Но ни Франция, ни Италия функцию форпоста вначале на себя не взяли. Тем не менее в 1948 г. к Бизонии присоединилась область, контролируемая Францией, и Бизония превратилась в Тризонию. 7 сентября 1949 г. она ушла в историю, уступив место ФРГ. Таким образом Бизония и Тризония как два организованных после Второй мировой войны образования стали искрами глобализационного развития Европы.

Западные страны и США возложили задачи противостояния социализму на ФРГ и стали вкладывать средства в ее возрождение. К тому же в 1949 г. создается Организация Североатлантического договора (НАТО) - военно-политический союз, направленный против социалистических стран, который был подписан 12 государствами. Позже эта организация пополнялась.

Получив финансовую помощь и защиту своих рубежей, германские идеологи осознают тот факт, что Европу можно завоевать без войны. Создавая вначале Европейское сообщество как политическую и экономическую организацию, объединившую «Европейское сообщество угля и стали» (1952 г.) с «Европейским экономическим сообществом» (1957 г.), «Европейским сообществом по атомной энергии» (1957 г.), Германия с 1993 г. переименовывает Европейское сообщество, которое к этому времени насчитывает 12 стран, в ЕС, а с 1990 г. ускоренному расширению ЕС способствовал развал СССР. К 1996 г. ЕС пополнился на 11 стран, позже заявки подали еще ряд стран, в том числе и Украина.

США не ожидали такой прыти от Германии, которая в знак своей финансовоэкономической независимости от США ввела свою валюту - евро, более укрепленную товаром, нежели доллар. И сбылась мечта Германии - она становится дефакто хозяйкой Европы.

В то же время в США идеологи изучают опыт Германии по глобализации Европы, и, видимо, дочитав вышеуказанную работу В. И. Ленина, обнаруживают призыв к созданию Соединенных штатов мира, фактически глобального мира. 
В 1980 г. появилась первая работа по глобализации Р. Робертсона, где она репрезентирована как процесс становления мира в виде единого социального пространства, обнаруживающего свою сущность в различных культурно-идеологических концептах. После работы Р. Робертсона возникает множество дефиниций этого концепта. Это обнаруживается у У. Бека, И. Валлерстайна [2004], К. Омаэ, М. Элброу, Э. Гидденса, И. Тирикьяна, Дж. Нейсбита и мн. др. На постсоветском пространстве учение о глобализации развивается в работах В. Л. Иноземцева, А. Н. Чумакова, В. Г. Воронковой, В. М. Лукашевича, И. Ф. Кефели, А. И. Зеленкова, М. Т. Махаматова, А. Д. Урсула, А. И. Уткина, Ю. В. Яковца и др. Идет интенсивный поиск теоретико-методологических платформ, на базе которых возможно было бы артикулированно выстроить аспекты глобализационного бытия человечества, идет бурное «достраивание» содержания концепта «глобализация». Такой процесс не нов, он характерен для каждой науки. Например, в квантовой механике - принцип дополнительности Н. Бора; в биохимии - принцип комплементарности; в математике - возникновение неевклидовой геометрии и т. д. Сегодня в социальной философии идет бурный процесс «достраивания» концептов «цивилизация», «техносфера», «инновационность», «духовно-нравственный потенциал общества и личности» и т. д. Е. Н. Князева, исследуя с позиций синергетического подхода процесс «достраивания» концепта «мышление», утверждает, что «в самодостраивании есть, по-видимому, элемент продвижения вперед, обновления, что является признаком творчества для высших когнитивных систем человеческих умов» [Князева 2013: 28]. Несомненно, это есть развитие и приращение знания. Среди новых радикальных зерен «достраивания» концепта «глобализация» можно выделить учение о триосфере, о социальных разломах глобального человечества и рисках неадекватного восприятия глобального мира - А. Н. Чумакова [2019], идеи о неоглобализации, ее признаках и принципах - Т. М. Махаматова [2017]; учение о взаимосвязи цивилизации, глобализации и культуры В. С. Степина [2011], А. И. Уткина [2001], Ю. В. Яковца [2003] и ряда других.

Процесс «достраивания» содержания концептов отражает степень личностного рационального понимания субъектом познающей проблемы, то есть его «геометрию» мышления. Она есть форма движения личностного знания субъекта, момент развития познания, форма проверки знания на научность и может выступать в качестве вызова позитивных сомнений в истине и конкретизирует этот процесс через адекватный эпохе методологический инструментарий. Но «геометрия» мышления на всех этапах развития научного знания предстает как концепт, обладающий смысловой «нагруженностью».

Особое исследование «геометрии» мышления обнаруживается у Б. Паскаля. Часто философы, обращаясь к проблеме становления методологии научного познания, апеллируют к работе А. Арно «Логика или Искусство мыслить», не указывая на заслуги других авторов этой работы, а ими были наряду с А. Арно профессор Пор-Рояля П. Николь, один из главных янсенистов Франции. Николь считал, что «самая надежная философия - это лишь наука о познании. Максимум познания - это познание минимумов нашего ума» [Таранов 1999: 346]. В то же 
время он отмечает разные способности ума, но задача ума заключается в достижении истины.

Третьим автором вышеуказанного трактата был Б. Паскаль. В 1655 г. он пишет работу «О геометрическом уме», которая вышла в качестве VI главы этого трактата, опубликованного в 1662 г. Характеризуя «геометрию мышления», Паскаль исходит из утверждения, что «все, что превышает геометрию, превосходит и нас» [Таранов 1999: 139], но мы бессильны проникнуть в сущность вещей. Этим утверждением он более чем на столетие опередил агностическую концепцию И. Канта «вещь в себе», утверждающую невозможность познания сущности вещей. По мнению Б. Паскаля, «геометрия» мышления отражает уровень наших интеллектуальных возможностей и личную «геометрию» ума, он раскрывает ее как противоречивый субъективный процесс. Аксиомой «геометрии» мышления выступает его утверждение, что человек создан для мышления; в этом все его достоинство; вся его заслуга и весь долг - мыслить как следует, хорошо мыслить [Там же: 127].

Как сложный многомерный феномен «геометрия» мышления представляет собой «опережающее, еще не подтвержденное практикой видение смысла и сущности исследуемой проблемы, это этап познавательной деятельности, состоящей в формировании умозаключений на основе эмпирических фактов и предшествующей выдвижению объясняющей их гипотезы» [Водопьянов, Бурак 2006: 76].

Анализируя «геометрию» мышления современных западных глобалистов, их подходы к объяснению сущности глобализации, к дефиниции этого социокультурного феномена, можно отметить их единство, солидарность и видение процесса формирования глобального мира. Реально видя процесс глобализации Европы под эгидой Германии, глобалисты США и Западной Европы центр стрелы направленности глобализации мира перенесли на США и начали раскручивать новый виток этого процесса.

В ходе «достраивания» концепта «глобализация» у них возникло много идей, в которых, однако, ярко прослеживается однородность в практически насильственном формировании глобального мира. Среди множества идей важно выделить: формирование однополярного мира, особенно после развала СССР; создание системы управления глобальным миром, где «первая скрипка» отдается США; объединение финансово-экономической сферы; управление мировой рабочей силой; объединение более 2000 народов в «единое село», без рассмотрения судеб народов, которые окажутся на околице этого «единого села», но это, как считают глобалисты, надо узаконить, чтобы не было столкновений их интересов с центром, не усугублялись противоречия.

Однако встает вопрос: с чего начинать? И здесь поднимается тема нового мирового порядка. А. Н. Чумаков отмечает, что «вопрос о мировом порядке такой же древний, как и мир общественных отношений, в котором мы живем... вопрос о новом мировом порядке вставал каждый раз, как только мировое сообщество в очередной раз пережило катастрофу или вплотную приближалось к ее черте» [Чумаков 2019: 310, 311 ]. 
Глобализация приблизила человечество к этой черте, но с чего начать наведение порядка, оно не знает. И как не вспомнить «Мысли» Б. Паскаля, в то время как мы являемся свидетелями наведения нового мирового порядка. «За политические писания (в данном случае - глобалисты. - О. П.) брались, как берутся наводить порядок в сумасшедшем доме и напускают при этом на себя важность» [Таранов 2002: 139].

Исследуя процесс становления глобального мира, ряд зарубежных глобалистов признает кризисное и даже хаотическое состояние переходного периода и предлагает свое видение решения проблем, не отклоняясь от общей оси задач по формированию этого мира, где превалируют субъективизм и зашоренность. Так, И. Валлерстайн в работе «Конец знакомого мира. Социология XXI века» отмечает, что «сложившаяся историческая система вступила в критическую фазу, когда неизбежны нарастание неопределенности и накопление кардинальных перемен, означающих, по сути, “конец знакомого мира", а зарождающиеся в точках бифуркации незначительные воздействия приводят к масштабным изменениям, последствия которых непредсказуемы» [Валлерстайн 2004: 13]. Он отдает предпочтение формированию социально-экономической и социально-политической систем как основных систем формирующегося глобального мира.

Односторонний подход к формированию такого мира обостряет проблемы столкновения и раскола цивилизаций [Хантингтон 2005; Иноземцев 1999], столкновение интересов, особенно ведущих стран современного мира [Чумаков 2019].

Большое заблуждение западных глобалистов заключается в игнорировании диалектики объективных условий и субъективного фактора. Объективные условия не находили своего отражения в их концепциях, приоритет отдавался субъективному фактору. Но природа преподнесла человечеству сюрприз в виде пандемии коронавируса - своеобразного объективного препятствия, на которое глобалисты и наткнулись. COVID-19 стал негативным «стартапом» раскола глобализирующего мира, а развернувшийся в этом мире хаос перерос в социальный страх, и природа в очередной раз дает человечеству шанс поумнеть во взаимоотношениях с ней.

\section{2. Синдром пандемии как исходная негативная стадия «стартапа» в социодинамике глобализирующегося мира}

Когда развернулись теоретические конструкты глобализационных процессов в пространстве мирового сообщества, встал основной вопрос: «Как сформировать глобальный мир?» Ни американские, ни проамериканские теоретики не обратили внимания на работу Н. Винера «Кибернетика», в которой он пишет, оценивая результаты первых промышленных революций, что у человечества «выход один построить общество, основанное на человеческих ценностях, отличных от куплипродажи. Для строительства такого общества потребуется большая подготовка и большая борьба, которая при благоприятных обстоятельствах может вестись в идейной плоскости, а в противном случае - кто знает как?» [Винер 2004: 96]. Из практики глобализации мира идейная плоскость вышеотмеченными идеологами была отброшена, выбор пал на второе, «кто знает как», в котором и возникли 
конфронтации, угрозы, санкции, применение «мягкой силы», конфликты, противоборство, то есть весь негативный «букет», отвечающий на этот вопрос. Но сегодня ведение большой войны между великими державами невозможно ввиду того, что экономическая глобализация накрепко связала всех, следовательно, война слишком дорого обойдется - ее следствием станут разрушение инфраструктуры стран, потеря человеческих ресурсов, особенно у тех государств, которые являются полюсами глобальной экономики. Поэтому в решение глобализационных задач включаются управленческие структуры страны, которые пытаются идеологически влиять на «строптивое» руководство самостоятельно развивающихся стран. Примеров здесь много. В частности, неудачный визит Ж. Борреля в Москву, где его главной задачей было подчинить руководство в России требованиям ЕС, а «лакмусовой бумагой» выступала идея несоблюдения демократических прав человека в России. В Брюсселе его визит охарактеризовали как крайне неудачный, в утешение Ж. Боррелю по его просьбе ввели санкции против России. Результаты таких визитов раскрывают двойные стандарты политики ЕС. Подобных примеров можно приводить массу, все они подтверждают игнорирование диалектического взаимодействия объективных условий и субъективного фактора, отдавая приоритет последнему.

Игнорирование диалектики объективного фактора и субъективных условий позволяет утверждать, что природные условия всегда давали шанс субъективному фактору «поумнеть» во взаимоотношениях с ней. Природа многократно заставляла человечество обращать внимание на отношение к ней через различные природные катаклизмы. Так, природа заставила обратиться к исследованию процессов извержения вулканов, и только после гибели Помпеи (79 г. н. э.) возникла наука вулканология. А в ноябре 1775 г. имела место всемирно известная катастрофа, когда за 6 минут от землетрясения в Португалии погибли 90 тысяч человек. Затем последовали подземные толчки, пожары и цунами, и страна в целом сильно пострадала. Власти Португалии потребовали дать ответ и от религии, и от науки. Религия сочла, что это кара Божья за колониальную политику страны, повлекшую человеческие жертвы, после чего Португалия отказалась от колониальных амбиций. Это событие широко обсуждалось в науке того времени и стало триггером (спусковым крючком) эпохи Просвещения. Оно заставило человечество изучать землетрясение как природный феномен, и возникла наука сейсмология. Природные явления, вызвавшие различные эпидемии и болезни, заставляли человечество искать причины их возникновения и средства борьбы с ними. Можно утверждать, что эпидемии и пандемии, охватывающие весь земной шар, дамокловым мечом висят над человечеством и время от времени опускаются на его голову. Среди них можно выделить прежде всего чуму, по выражению А. С. Пушкина, «царицу грозную». Еще в шумерской и аккадской мифологиях значительное место уделяется богу чумы - Эрру, ужасному истребителю и опустошителю равнин, нагонявшему ужас на богов, демонов, царей гор и морей. Исследователи этой болезни [Крамер 1977: 154; Водопьянов, Крисаченко 2018: 216] и другие отмечают ее как «моровую болезнь», в 490-495 гг. до н. э. описанную крупнейшим древнегреческим историком и философом Фукидидом; «моровая чума» была 
во времена Антониана (165-180 гг. н. э.); в 531-580 гг. свирепствовала «чума Юстиниана». Самая страшная эпидемия чумы пришлась на XIV в., унеся с собой, по разным подсчетам, от 25 до 50 млн жизней [Бароян 1967: 60]. Эта «царица» прокатилась по Руси, Украине, Китаю, Индии, Европе. Исследователи этой болезни практически не рассматривают такой ее вид, как «танцевальная чума», которая возникла в Страсбурге в 1518 г. Люди пускались в пляс, и танцующие заполнили все улицы города. Сначала их воспринимали как чудаков, но вскоре осознали, что люди не могут остановиться. Они стирали ноги в кровь, теряли сознание, многие скончались от инсультов. Но в том же году эта эпидемия завершилась, свидетелем «танцевальной чумы» стал известный художник Питер Брейгель Старший, запечатлевший ее на полотне.

Помимо чумы человечество пережило оспу, холеру, дифтерию, корь, грипп в различных его формах (особенно опасной его формой была испанка, унесшая более 75 млн человеческих жизней), лихорадку, СПИД. Сегодня человечество переживает новую пандемию - COVID-19, охватившую практически все страны мира и по текущей статистике по коронавирусу на 23.11.2021 (во всем мире) обрушилась на более чем 258 млн человеческих жизней. И сегодня можно согласиться с А. Н. Чумаковым, что «проблема здравоохранения преодолела не только локальные, но и региональные границы и вышла на глобальный уровень» [Чумаков 2020: 8], то есть здравоохранение стало одной из составляющих глобальных проблем человечества. Ее главной задачей выступает поиск путей и стратегии выживания человечества.

Глобализация, столкнувшись с COVID-19, резко снизила рост темпов всех сфер материального, духовного и информационного производства. COVID-19 предстал как глобальный гео-, био-, социальный «квант» негативного воздействия на социально-экономические, коэволюционные, медицинские процессы, как исходная негативная стадия «стартапа» в социодинамике глобализирующегося мира, как отклик природы на отношение к ней человека, как ее месть человечеству за его хищническую стратегию природопользования. Понятие «квант» используется для исследования и понимания основы большинства макрообразований. Так, Х. Ортега-и-Гассет в работе «Восстание масс» утверждает, что таким макрообразованием является понятие «европеец». Он пишет, что «в каждом из нас европеец значительно преобладает над немцем, испанцем, французом. Современный человек не может жить только тем, что есть в нем "своего" национального: четыре пятых нашего внутреннего богатства - общеевропейское достояние» [Ортега-иГассет 1989: 150]. Таким же образованием у М. Галича выступает цивилизация, когда он обнаруживает общее более чем у 30 цивилизаций в Латиноамериканском регионе в доколумбовую эпоху [Галич 1990].

COVID-19 - это, по заявлениям BO3, природный патоген, и борьбу с ним необходимо вести через тесное сотрудничество, видеть стремление ряда стран преодолеть пандемию и исходить в своем поведении из завета, что «в трудные времена мудрые строят мосты, а глупцы - стены». И нет смысла обвинять Китай в «открытии» этой пандемии (а сейчас в информационном пространстве Интернета обвиняют и США в разработке этого патогена), почву для его возникновения 
подготовило все человечество. И если сегодня проигнорировать сотрудничество стран по борьбе с COVID-19, исходя из политических стремлений, то его «моровое» шествие по всему миру резко возрастет. «Стартап» этого патогена резко усилит раскол всех сфер общественного бытия.

COVID-19 резко обострил ритм приспособленности людей к условиям бытия в глобальном мире. И в условиях распада обычных форм организации жизни люди научились как-то выживать и приспосабливаться к нестабильному, неопределенному, негарантированному существованию. Эта адаптация стала природной реакцией на негативизм глобализационных процессов, а COVID-19 не просто внес социальный хаос в сложившийся ритм жизни, а перерос в социальный страх.

Встает проблема самоорганизации общественного бытия. Теоретические конструкты самоорганизации заложены в синергетическом подходе. С позиций его применения самоорганизация предстает как «понятие, характеризующее важнейшее свойство объективного мира (систем), его способность к внутренней самоорганизованности в случае изменения внешних условий существования, препятствующих достижению данными системами устойчивого положения в этой среде. Самоорганизация... - способность систем различной природы... к самопроизвольной, внутренне детерминированной активности в направлении роста их организованности в складывающейся негативной среде существования. Для социальных систем точками такой самоорганизации выступает фактор разумности человека» [Шалаев 2009: 345].

Для характеристики сложных социальных систем наука выделяет ряд режимов функционирования: первый отражает конструктивное прогрессивное развитие; второй - регресс (спад) развития; третий - одностороннее развитие; четвертый - застой, переходящий в стагнацию системы. Сегодня в единое целое объединились второй и четвертый режимы функционирования социальной системы. Применительно к современному состоянию общества, сегодня «режим застоя можно охарактеризовать следующими показателями: низкий уровень коллективного разума; слабое внедрение социальных инноваций; размытость моральных, правовых и других норм; изоляция отдельных социальных групп и институтов; бездуховность; ориентация членов общества преимущественно на стереотипные образцы действий в различных сферах и отсутствие ориентаций на движение вперед» [Воронкова 2012: 18].

С позиций самоорганизации системы COVID-19 предстал как препятствие, о которые разбились глобализационные конструкции. К. Шваб, известный основатель и бессменный руководитель Всемирного экономического форума, и футуролог Т. Маллере выпустили книгу «COVID-19: The Great Reset», что можно перевести как «великая перестройка» или «великая перезагрузка». В Интернете используется второй термин (наверное, потому, что великую горбачевскую перестройку мы пережили, правда, еще не полностью). Авторы работы на вопрос «Когда же мы вернемся к нормальной жизни?» отвечают: «Никогда». Историю глобализации они делят на два периода: до пандемии и после нее. До пандемии история нам известна, настоящая история для нас еще загадка, поскольку неиз- 
вестно, когда она закончится, а вот период будущего развития общества после пандемии несколько утопичен.

Основные удары пандемия нанесла по политическим аспектам формирования глобального мира и управления им; по экономике и финансам ведущих стран и объединений мира; по коэволюционным процессам, по социальной сфере деятельности человечества. Общая характеристика этих направлений глобализирующегося мира показывает, что COVID-19 внес раскол в вышеотмеченные направления общественного развития. Но остановимся на первых двух.

Во-первых, политический аспект характеризуется расколом между основными игроками мира сего: США, Россией, Китаем и ЕС, а это вносит раскол и в политические отношения мира в целом. В истории так совпало, что во время пандемии в ряде стран происходит смена лидеров, а это означает смену курса взаимоотношений между странами. Произошла скандальная смена президента США. Почему скандальная? В истории США Капитолий штурмовали дважды: в XIX в. англичане и в январе 2021 г. - республиканцы, не согласные с итогами выборов. Речь идет не только о разногласиях в экономических программах демократов и республиканцев, но и о ценностях, устоях, образе жизни, которые у американцев серьезно различаются. Фактически внутренняя политика США оказалась расколотой.

Что же касается внешней политики США, то Дж. Байден сразу же отменил указ Д. Трампа о разрыве договора СНВ-3, и это стало единственным значимым событием для мирового сообщества. Все остальные аспекты взаимоотношений США и России лишь углубляют их противостояние, что характеризуется ростом санкций со стороны США в адрес России (в том числе по «Северному потоку-2», по «делу Навального» и др.).

В условиях пандемии разрушаются связи между США и Китаем, который становится лидером в экономическом развитии. Китай довольно ощутимо отвечает на санкции США и ЕС, и мир воочию убеждается, что сегодня исчезают основания для того, чтобы богатые страны могли вмешиваться в дела других государств. И нынешнюю эпоху можно охарактеризовать как глобализацию под китайским экономическим лидерством.

Еще одна проблема для США заключается в том, что Дж. Байден не знает, как будут развиваться отношения с ЕС. В этом году сменится канцлер в Германии. На данный момент известно лишь, что партия А. Меркель провалилась на выборах в Баден-Вюртемберге и Рейнланд-Пфальце, традиционно считавшихся оплотами христианских демократов, и это резко снизило шансы ХДС остаться у власти после выборов в Бундестаг. К тому же неизвестно, кто станет после выборов президентом Франции. А в ЕС также имеет место серьезный раскол, особенно в условиях пандемии. Реализовался Brexit, в Италии ушел в отставку Д. Конте, назвавший кризис из-за пандемии коронавируса «самым большим испытанием со времен Второй мировой войны»; Франция сегодня ставит вопрос о выходе из ЕС; Германия также признает процесс раскалывания ЕС. Так, известный немецкий политолог А. Рар утверждает, что ЕС был создан для «хорошей погоды», был европейской витриной, куда тянулись все страны Европы. Однако для трудных 
времен он оказался непригодным, каждая страна стремилась перетянуть «финансовое одеяло» на себя, но многим это не удалось. Единственным консолидирующим фактором ЕС выступает НАТО, защищая его от угрозы России.

В условиях пандемии масла в «огонь раскола» подлили выборы в Белоруссии. Оппозиция в этой стране ни разу не поднимала вопрос о пересмотре основных положений Конституции, в том числе и о сроках пребывания на посту президента. Но прошли выборы, и оппозиция проснулась: С. Тихановская заявила, что она не согласна с результатами подсчета голосов. За помощью она обратилась к Литве и Польше, которые оказались готовы к такому шагу. И в Белоруссии разворачивается сценарий белорусской цветной революции. Идут митинги, снизились темпы промышленного и сельскохозяйственного производства. Сорос, «соросята», Литва и Польша торжествуют - внесен хаос в последний оплот России. «Железный занавес» Черчилля передвигается на границу с Россией от Балтийского до Черного моря.

Однако С. Тихановская забыла, сколько лет Белоруссия находилась под игом Литвы и Польши и как пострадала страна от немцев во Второй мировой войне. Уровень политического интеллектуального развития Тихановской виден из ее ответов в интервью, которое опубликовал «Медиакурьер в Украине» (17-23 февраля 2021 г.), где на 90 \% вопросов журналиста она отвечает фразой «Так хочет белорусский народ». Откуда у нее такая информация? В Белоруссии живут 9,5 млн человек, участвовало в акциях 200-250 тысяч, а мнение остальных ее не интересует. И еще: и она, и ее окружение заявляют, что А. Лукашенко находится в безвыходной ситуации, забывая при этом об утверждении Б. Шоу, который писал, что «безвыходных ситуаций не бывает, есть ситуации, выход из которых вас не устраивает». А что если Лукашенко введет Белоруссию в состав России в качестве федерации? Запад это понимает из заявления В. В. Путина по Белоруссии, а Тихановская - нет.

Из вышесказанного видно, что политический раскол состояния глобализирующегося мира не способствует установлению на планете нового мирового порядка.

Что же касается развития экономической и финансовой сферы, то здесь дела обстоят не лучшим образом. За время пандемии резко снизились экономические показатели ряда стран. Прежде всего это падение ВВП. В США он упал почти на $3 \%$, в ЕС - на 2,2 \%, в России и Китае перешагнул порог 3 \%; на Украине снижение достигает 5 \%. Украина обратилась в ЕС по поводу ускоренного пересмотра условий вхождения в ЕС и проиграла в том отношении, что ЕС требует перехода Украины на стандарты этого союза и цифровизацию, и это не ускоряет приближение входа Украины в союз, а отдаляет. Международные организации не поддерживают Украину извне, а выдвигают требования, еще более разоряющие страну. Так, МВФ потребовал продажи украинской земли, и президент Украины В. А. Зеленский вместе с Верховной Радой под аплодисменты приняли этот закон, но что осталось продавать? К тому же страна с 2014 г. находится в сложных отношениях с Россией, считая ее агрессором (политический аспект), а ведь РФ и оставшиеся члены СНГ - это большой рынок сбыта некачественной украинской 
продукции. Теперь он перекрыт, а обращение к ЕС оказалось провальным. Не может же Европейский союз по квоте распределять украинский промышленный брак и сельскохозяйственную некачественную продукцию. К тому же на Западе хорошо знают «Капитал» К. Маркса.

Экономика, как считают глобалисты, может возродиться через два-три года и глобализация расцветет в своем новом качестве. Здесь глобалисты исходят из идей К. Шваба и Т. Маллере, которые утверждают, что пандемия стала «окном возможностей» для перестройки мира, базой формирования нового глобального мира. Следовательно, первой жертвой пандемии становится новый мировой порядок, в сфере которого США потеряли лидерство, особенно после штурма Капитолия, и все в стране идет к огромному экономическому кризису, который затмит и Великую депрессию, и крах после 11 сентября 2001 г. Однако К. Шваб утверждает, что пандемия - это реальная возможность «перезагрузить» экономику мира в пользу более экологичной и социально ориентированной модели развития глобализации. Но «перезагрузка» должна проходить под флагом капитализма, это четко просматривается в концепции Шваба, поскольку «перезагрузку» он рассматривает с точки зрения интересов капитала и максимизации его прибыли, а четвертая промышленная революция решает эту проблему с огромным ускорением. Экономика должна централизованно управляться гигантскими монополиями, государственные границы будут стерты, и таким образом возникает единое государство с единым правительством. И опять же - рулевым провозглашаются США, они устанавливают новые порядки во всех сферах бытия общества, например, освобождают капитал от издержек социальных выплат. Национальному же государству в новом глобальном мире места нет. А где же в этой утопии человек? Его нет в четвертой промышленной революции, он «отменяется», это балласт для капитала. И, по мнению Шваба, его заменят искусственный интеллект, роботизация, биотехнологии.

Встает вопрос, насколько хорошо авторы «Великой перезагрузки» помнят историю первой промышленной революции, повлекшей буржуазные революции, 400 лет бушевавшие в Европе. Не будет ли пандемия новой точкой отсчета мирового переустройства, когда каждая страна станет развиваться по своей стезе, будет иметь право на свое национальное развитие, реализацию своих интересов, а не выполнять указания извне? К. Шваб забыл, что постпандемическая глобализация, в его видении, отбрасывает все демократические начала, за которые радеют США и ЕС.

Да, экономика стран рухнула, она возродится через небольшой срок, но на ее теле останутся раны, которые будут долго заживать.

Что же касается финансовой сферы, то цель введения биткоина - это спасение от падения доллара и отказа от него ряда стран. Так, Индия приняла закон, запрещающий вести расчеты через биткоин, она не хочет исчезновения денег и введения цифровой валюты. А К. Шваб пропагандирует необходимость перехода к цифровой валюте. Но утверждение власти цифры, цифровизация всех сфер жизни человека - это прямое следствие закона самовозрастания капитала, предпринимательской экономики, основанной на принципе получения максимальной прибыли 
идеологией экономизма, репрезентирующей ее в качестве одной из сторон «великой перезагрузки».

Реально же сегодня укрепляется юань в качестве будущей валюты постпандемического глобального мира.

Несомненно, глобализация после пандемии не уйдет в анналы истории человечества, но она должна осуществляться как форма подлинной интеграции человечества, реализовываться ради решения общих проблем, для достижения высших идей и целей.

\section{Литература}

Бароян О. В. Победа над эпидемиями // Природа. 1967. № 11.

Валлерстайн И. Конец знакомого мира. Социология XXI в. М. : Логос, 2004.

Винер Н. Кибернетика или управление и связь в животном и машине // Информационное общество: сб. / сост. А. Лактионов. М. : АСТ, 2004. С. 45-218. 2006.

Водопьянов П. А., Бурак П. М. Философия и методология науки. Минск : БГТУ,

Водопьянов П. А., Крисаченко В. С. Стратегия бытия человечества. Минск : Беларуская навука, 2018.

Воронкова В. Г. Місце і роль синергетики у пізнанні соціальних процесів та розвитку сучасного суспільства // Гуманітарний вісник ЗДІА. Зб. наук. праць. Вип. 48. Запоріжжя: ЗДІА, 2012. С. 5-24.

Галич М. История доколумбовых цивилизаций. М. : Мысль, 1990.

Иноземцев В. Л. Расколотая цивилизация. М. : Academia-Наука, 1999.

Князева Е. А. Сложное мышление / Э. Морен, Ф. Варела, К. Майнцер // Философия мышления. Одесса : Печатный дом, 2013. С. 17-38.

Крамер С. Н. Мифология Шумера и Аккоды // Мифология древнего мира / отв. ред. В. А. Якобсон. М. : Азбука-классика, 1977.

Маккиндер Х. Дж. Географическая ось истории. М. : АСТ, 2003.

Махаматов Т. М. От эпохи глобализации к неоглобализации: культурно-цивилизационный аспект // Век глобализации. 2017. № 4 (24). С. 55-61.

Ортега-и-Гассет Х. Восстание масс, XIV, 9 // Вопросы философии. 1989. № 4.

Родрик Д. Парадокс глобализации: демократия и будущее мировой экономики. М. : Изд-во Ин-та Гайдара, 2014.

Степин В. С. Цивилизация и культура. СПб. : СПбГУП, 2011.

Таранов П. С. Золотая философия. М. : АСТ, 1999.

Таранов П. С. 120 философов. Б. Паскаль. Симферополь : Реноме, 2002. С. 125-144.

Уткин А. И. Глобализация: процесс и осмысление. М. : Логос, 2001.

Фернандес-Арместро Ф. Цивилизации. М. : АСТ; АСТ-Москва, 2009.

Хантингтон С. Столкновение цивилизаций и преобразование мирового порядка. M. : АCT, 2005.

Чумаков А. Н. Глобальный мир: столкновение интересов. М. : Проспект, 2019. 
Чумаков А. Н. Глобалистика в контексте современности: испытание пандемией // Век глобализации. № 3. 2020. С. 3-14.

Шалаев В. П. Синергетика в пространстве философских проблем современности. Йошкар-Ола : МГТУ, 2009.

Яковец Ю. В. Глобализация и взаимодействие цивилизаций. М. : Экономика, 2003.

\section{References}

Baroyan O. V. Pobeda nad epidemiyami [Victory Over Epidemics] // Priroda. 1967. No. 11.

Wallerstein I. Konets znakomogo mira. Sotsiologiya HHI v. [The End of the World as We Know. Social Science for the XXI Century]. Moscow : Logos, 2004.

Wiener N. Kibernetika ili upravlenie i svyaz v zhivotnom i mashine [Cybernetics Or Control and Communication in the Animal and the Machine] // Informatsionnoe obshestvo. Moscow : AST, 2004. Pp. 45-218.

Vodopyanov P. A., Burak P. M. Filosofiya i metodologiya nauki [Philosophy, and Methodology of Science]. Minsk : BGTU, 2006.

Vodopyanov P. A., Krisachenko V. S. Strategiya bytiya chelovechestva [The Strategy of Human Existence]. Minsk : Belaruskaya Navuka, 2018.

Voronkova V. G. Misce i rol sinergetiki u piznanni sotsialnih protsesiv ta rozvitku suchasnogo suspilstva [The Place and Role of Synergetics in the Knowledge of Social Processes and the Development of Modern Society] // Gumanitarnij visnik ZDIA. Zb. nauk. prac. Vol. 48. Zaporizhzhya : ZDIA, 2012. Pp. 5-24.

Galich M. Istoriya dokolumbovyh tsivilizatsij [History of Pre-Columbian Civilizations]. Moscow : Mysl, 1990.

Inozemtsev V. L. Raskolotaya tsivilizatsiya [A Shattered Civilization]. Moscow : Academia-Nauka, 1999.

Knyazeva E. A. Slozhnoe myshlenie: E. Moren, F. Varela, K. Majncer [Complex Thinking: E. Morin, F. Varela, K. Mainzer] // Filosofiya myshleniya. Odessa : Pechatnyj dom, 2013. Pp. 17-38.

Kramer S. N. Mifologiya Shumera i Akkody [The Mythology of Sumer and Akkoda] // Mifologiya drevnego mira / ed. by V. A. Yakobson. Moscow : Azbuka-klassika, 1977.

Mackinder H. J. Geograficheskaya os istorii [Geographical Pivot of History]. Moscow : AST, 2003.

Mahamatov T. M. Ot epohi globalizatsii k neoglobalizatsii: kulturno-tsivilizatsionnyj aspekt [From the Era of Globalization to Neoglobalization: The Cultural and Civilizational Aspect] // Vek globalizatsii. 2017. No. 4 (24). Pp. 55-61.

Ortega-i-Gasset H. Vosstanie mass, XIV, 9 [Rise of the Masses, XIV, 9] // Voprosy filosofii. 1989. No. 4.

Rodrik D. Paradoks globalizatsii: demokratiya i budushee mirovoj ekonomiki [The Globalization Paradox: Democracy and the Future of the World Economy]. Moscow : The Gaidar Institute Publishing, 2014. 
Stepin V. S. Tsivilizatsiya i kultura [Civilization and Culture]. St. Petersburg : SPbGUP, 2011.

Taranov P. S. Zolotaya filosofiya [Golden Philosophy]. Moscow : AST, 1999.

Taranov P. S. 120 filosofov. B. Paskal [120 Philosophers. B. Pascal]. Simferopol : Renome, 2002. Pp. 125-144.

Utkin A. I. Globalizatsiya: Process i Osmyslenie [Globalization: Process and Reflection]. Moscow : Logos, 2001.

Fernandes-Armestro F. Tsivilizatsii [Civilizations]. Moscow : AST; AST-Moskva, 2009.

Huntington S. Stolknovenie tsivilizatsij I preobrazovanie mirovogo poryadka [The Clash of Civilizations and the Remaking of World Order]. Moscow : AST, 2005.

Chumakov A. N. Globalnyj mir: stolknovenie interesov [Global World: The Clash of Interests]. Moscow : Prospekt, 2018.

Chumakov A. N. Globalistika v kontekste sovremennosti: ispytanie pandemiej [Globalistics in the Context of Modernity: A Pandemic Test] // Vek globalizatsii. 2020. No. 3. Pp. 3-14.

Shalayev V. P. Sinergetika v prostranstve filosofskih problem sovremennosti [Synergetics in the Space of Modern Philosophical Problems]. Joshkar-Ola : Bauman University, 2009.

Yakovets Yu. V. Globalizatsiya i vzaimodejstvie tsivilizatsij [Globalization and Interaction of Civilizations]. Moscow : Ekonomika, 2003. 